San Jose State University

SJSU ScholarWorks

Mineta Transportation Institute Publications

$11-2020$

\title{
Cost-Benefit Analysis of Novel Access Modes: A Case Study in the San Francisco Bay Area
}

\author{
Caroline Rodier \\ University of California, Davis \\ Andrea Broaddus \\ Mineta Transportation Institute \\ Miguel Jaller \\ University of California, Davis \\ Jeffery Song \\ University of California, Davis \\ Joschka Bischoff \\ Mineta Transportation Institute
}

See next page for additional authors

Follow this and additional works at: https://scholarworks.sjsu.edu/mti_publications

Part of the Transportation Commons

\section{Recommended Citation \\ Caroline Rodier, Andrea Broaddus, Miguel Jaller, Jeffery Song, Joschka Bischoff, and Yunwan Zhang. "Cost-Benefit Analysis of Novel Access Modes: A Case Study in the San Francisco Bay Area" Mineta Transportation Institute Publications (2020). https://doi.org/10.31979/mti.2020.1816}

This Report is brought to you for free and open access by SJSU ScholarWorks. It has been accepted for inclusion in Mineta Transportation Institute Publications by an authorized administrator of SJSU ScholarWorks. For more information, please contact scholarworks@sjsu.edu. 


\section{Authors}

Caroline Rodier, Andrea Broaddus, Miguel Jaller, Jeffery Song, Joschka Bischoff, and Yunwan Zhang 


\section{Mineta Transportation Institute}

Founded in 1991, the Mineta Transportation Institute (MTI), an organized research and training unit in partnership with the Lucas College and Graduate School of Business at San José State University (SJSU), increases mobility for all by improving the safety, efficiency, accessibility, and convenience of our nation's transportation system. Through research, education, workforce development, and technology transfer, we help create a connected world. MTI leads the Mineta Consortium for Transportation Mobility (MCTM) funded by the U.S. Department of Transportation and the California State University Transportation Consortium (CSUTC) funded by the State of California through Senate Bill 1.

MTI focuses on three primary responsibilities:

\section{Research}

MTI conducts multi-disciplinary research focused on surface transportation that contributes to effective decision making. Research areas include: active transportation; planning and policy; security and counterterrorism; sustainable transportation and land use; transit and passenger rail; transportation engineering; transportation finance; transportation technology; and workforce and labor. MTI research publications undergo expert peer review to ensure the quality of the research.

\section{Education}

To ensure the efficient movement of people and products, we must prepare a new cohort of transportation professionals who are ready to lead a more diverse, inclusive, and equitable transportation industry. To help achieve this, MTI sponsors a suite of workforce development and education opportunities. The Institute supports educational programs offered by the Lucas Graduate School of Business: a Master of
Science in Transportation Management, plus graduate certificates that include High-Speed and Intercity Rail Management and Transportation Security Management. These flexible programs offer live online classes so that working transportation professionals can pursue an advanced degree regardless of their location.

\section{Information and Technology Transfer}

MTI utilizes a diverse array of dissemination methods and media to ensure research results reach those responsible for managing change. These methods include publication, seminars, workshops, websites, social media, webinars, and other technology transfer mechanisms. Additionally, MTI promotes the availability of completed research to professional organizations and works to integrate the research findings into the graduate education program. MTI's extensive collection of transportation-related publications is integrated into San José State University's world-class Martin Luther King, Jr. Library.

\section{Disclaimer}

The contents of this report reflect the views of the authors, who are responsible for the facts and accuracy of the information presented herein. This document is disseminated in the interest of information exchange. MTI's research is funded, partially or entirely, by grants from the U.S. Department of Transportation, the U.S. Department of Homeland Security, the State of California, and the California Department of Transportation, whom assume no liability for the contents or use thereof. This report does not constitute a standard specification, design standard, or regulation. 
Report 20-46

\title{
Cost-Benefit Analysis of Novel Transit Access Modes: A Case Study in the San Francisco Bay Area
}

\author{
Caroline Rodier, $\mathrm{PhD}$ \\ Andrea Broaddus, $\mathrm{PhD}$ \\ Miguel Jaller, $\mathrm{PhD}$ \\ Jeffery Song, $\mathrm{PhD}$ \\ Joschka Bischoff, PhD \\ Yunwan Zhang
}

November 2020

A publication of the Mineta Transportation Institute

Created by Congress in 1991

College of Business

San José State University

San José, CA 95192-0219 


\section{TECHNICAL REPORT DOCUMENTATION PAGE}

\begin{tabular}{|c|c|c|c|}
\hline $\begin{array}{l}\text { 1. Report No. } \\
20-46\end{array}$ & 2. Government Accession No. & \multicolumn{2}{|c|}{ 3. Recipient's Catalog No. } \\
\hline \multirow{2}{*}{\multicolumn{2}{|c|}{$\begin{array}{l}\text { 4. Title and Subtitle } \\
\text { Cost-Benefit Analysis of Novel Access Modes: A Case Study in the San } \\
\text { Francisco Bay Area }\end{array}$}} & \multicolumn{2}{|c|}{$\begin{array}{l}\text { 5. Report Date } \\
\text { November } 2020\end{array}$} \\
\hline & & \multicolumn{2}{|c|}{ 6. Performing Organization Code } \\
\hline \multicolumn{2}{|c|}{$\begin{array}{l}\text { 7. Authors } \\
\text { Caroline Rodier, PhD (0000-0002-9107-5547), Andrea Broaddus, PhD (0000- } \\
\text { 0003-3175-5986), Miguel Jaller, PhD (0000-0003-4053-750X), Jeffery Song, } \\
\mathrm{PhD} \text { (0000-0002-0964-8888), Joschka Bischoff, PhD (0000-0002-2262-7475), } \\
\text { Yunwan Zhang (0000-0003-3706-4625) }\end{array}$} & \multicolumn{2}{|c|}{$\begin{array}{l}\text { 8. Performing Organization } \\
\text { Report } \\
\text { CA-MTI-1816 }\end{array}$} \\
\hline \multirow{2}{*}{\multicolumn{2}{|c|}{$\begin{array}{l}\text { 9. Performing Organization Name and Address } \\
\text { Mineta Transportation Institute } \\
\text { College of Business } \\
\text { San José State University } \\
\text { San José, CA 95192-0219 }\end{array}$}} & \multicolumn{2}{|c|}{ 10. Work Unit No. } \\
\hline & & \multicolumn{2}{|c|}{$\begin{array}{l}\text { 11. Contract or Grant No. } \\
\text { 69A3551747127 }\end{array}$} \\
\hline \multirow{2}{*}{\multicolumn{2}{|c|}{$\begin{array}{l}\text { 12. Sponsoring Agency Name and Address } \\
\text { U.S. Department of Transportation Office of the Assistant Secretary for } \\
\text { Research and Technology University Transportation Centers Program } 1200 \\
\text { New Jersey Avenue, SE } \\
\text { Washington, DC 20590 }\end{array}$}} & \multicolumn{2}{|c|}{$\begin{array}{l}\text { 13. Type of Report and Period } \\
\text { Covered } \\
\quad \text { Final Report } \\
\end{array}$} \\
\hline & & \multicolumn{2}{|c|}{ 14. Sponsoring Agency Code } \\
\hline \multicolumn{4}{|l|}{$\begin{array}{l}\text { 15. Supplemental Notes } \\
\text { DOI: } 10.31979 / \mathrm{mti} .2020 .1816\end{array}$} \\
\hline \multicolumn{4}{|c|}{$\begin{array}{l}\text { 16. Abstract } \\
\text { The first-mile, last-mile problem is a significant deterrent for potential transit riders, especially in suburban } \\
\text { neighborhoods with low density. Transit agencies have typically sought to solve this problem by adding parking } \\
\text { spaces near transit stations and adding stops to connect riders to fixed-route transit. However, these measures are } \\
\text { often only short-term solutions. In the last few years, transit agencies have tested whether new mobility services, such } \\
\text { as ridehailing, ridesharing, and microtransit, can offer fast, reliable connections to and from transit stations. However, } \\
\text { there is limited research that evaluates the potential impacts of these projects. Concurrently, there is growing interest } \\
\text { in the future of automated vehicles (AVs) and the potential of AVs to solve this first-mile problem by reducing the } \\
\text { cost of providing these new mobility services to promote access to transit. This paper expands upon existing research } \\
\text { to model the simulate the travel and revenue impacts of a fleet of automated vehicles that provide transit access } \\
\text { services in the San Francisco Bay Area offered over a range of fares. The model simulates a fleet of AVs for first-mile } \\
\text { transit access at different price points for three different service models (door-to-door ridehailing and ridesharing } \\
\text { and meeting point ridesharing services). These service models include home-based drop-off and pick-up for single } \\
\text { passenger service (e.g., Uber and Lyft), home-based drop-off and pick-up for multi-passenger service (e.g., } \\
\text { microtransit), and meeting point multi-passenger service (e.g., Via). }\end{array}$} \\
\hline $\begin{array}{l}\text { 17. Key Words } \\
\text { public transit, intelligent vehicles, } \\
\text { dynamic models, ridership, transit } \\
\text { operators }\end{array}$ & $\begin{array}{l}\text { 18. Distribution Statement } \\
\text { No restrictions. This document is av: } \\
\text { public through The National Techni } \\
\text { Service, Springfield, VA } 22161\end{array}$ & $\begin{array}{l}\text { ible to the } \\
\text { Information }\end{array}$ & \\
\hline $\begin{array}{l}\text { 19. Security Classif. (of this report) } \\
\text { Unclassified }\end{array}$ & $\begin{array}{l}\text { 20. Security Classif. (of this page) } \\
\text { Unclassified }\end{array}$ & $\begin{array}{l}\text { 21. No. of Pages } \\
37\end{array}$ & 22. Price \\
\hline
\end{tabular}

Form DOT F 1700.7 (8-72) 
Copyright (C) 2020

\section{by Mineta Transportation Institute}

All rights reserved.

DOI: $10.31979 / \mathrm{mti} .2020 .1816$

Mineta Transportation Institute College of Business

San José State University San José, CA 95192-0219

Tel: (408) 924-7560

Fax: (408) 924-7565

Email: mineta-institute@sjsu.edu

$\underline{\text { transweb.sjsu.edu/research/1816 }}$ 


\section{ACKNOWLEDGMENTS}

The authors thank the Mineta Transportation Institute for funding this work.

Cover image: Illustration by Isabel Foo, The Global and Mail, https://www.theglobeandmail.com/business/adv/article-can-smart-mobility-solutions-answertransits-firstlast-mile/. 


\section{CONTENTS}

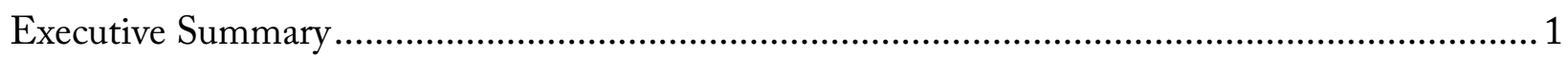

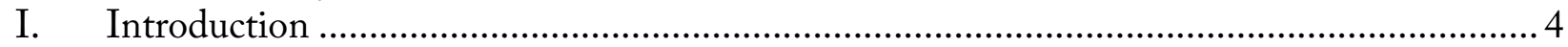

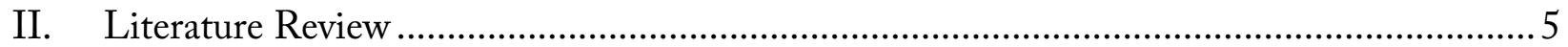

2.1 Modeling First/Last Mile Services ……………............................................................ 5

2.2 Fare Costs for First/Last-Mile Services ......................................................................... 7

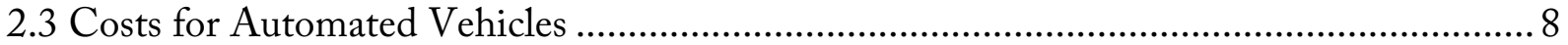

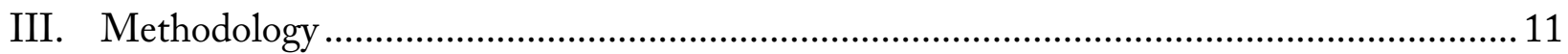

3.1 Model Description ..................................................................................................... 11

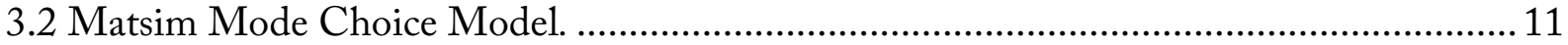

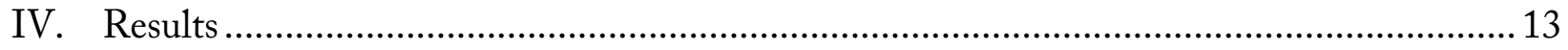

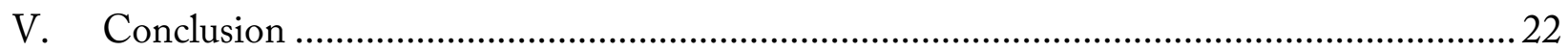

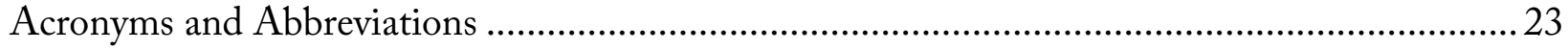

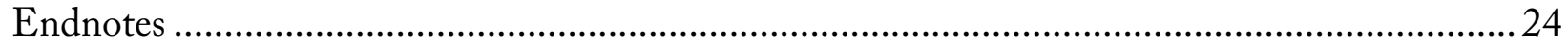

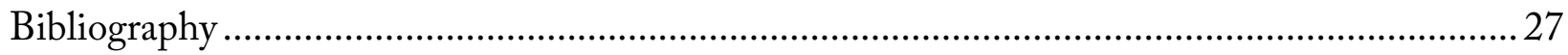

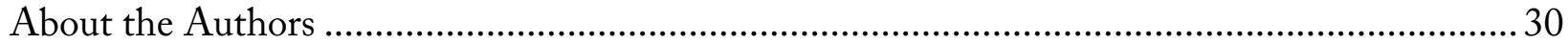




\section{LIST OF FIGURES}

Figure 1. Service rides by service type and fare............................................................ 13

Figure 2. Average travel time (seconds) by service type and fare .......................................... 14

Figure 3. Average wait time per passenger (in seconds) by service type and fare...................... 15

Figure 4. Lambda (detour ratio) by service type and fare ................................................... 16

Figure 5. The number of miles traveled by service type and fare ........................................... 16

Figure 6. The zero passenger miles traveled (i.e., the number of miles traveled by the AVs with no passengers) for each scenario................................................................. 17

Figure 7. The vehicle miles traveled by personal vehicle by service type and fare...................... 18

Figure 8. Total distance traveled by service type and fare .................................................... 19

Figure 9. The total revenue by service type and fare ......................................................20

Figure 10. Low operating costs and revenue by service type and fare...................................21

Figure 11. High operating costs and revenue by service type and fare .................................21 


\section{LIST OF TABLES}

Table 1. Typology and Fares of First- and Last-Mile Pilot Programs in the United States ......... 8

Table 2. Estimates of Future Costs of Automated Vehicles................................................... 10 


\section{Executive Summary}

The first-mile, last-mile problem is a significant deterrent for potential transit riders, especially in less dense, suburban neighborhoods. Transit agencies have typically sought to solve this problem by adding parking spaces near transit stations and adding stops to connect riders to fixed-route transit. However, this is often just a short-term solution. In the last few years, agencies piloted projects to test whether new mobility services, such as ridehailing, ridesharing, and microtransit, can offer fast, reliable connections to and from transit stations. However, there is limited research that evaluates the potential impacts of these projects. Furthermore, there is a growing interest in the future of automated vehicles (AVs) and their potential to better address the first-mile problem by reducing the cost of providing these new mobility services to access transit.

In this study, the San Francisco Bay Area MATSim model (BA-MATSim) was used to model the potential impacts of automated microtransit vehicles on transit use in the San Francisco Bay Area. The BA-MATSim model was developed at the Institute of Transportation Studies, University of California at Davis. The model simulates the travel and revenue effects of first-mile, last-mile access services over a range of fares. These services use a fleet of automated vehicles to provide home-based drop-off and pick-up for single passenger service (e.g., Uber and Lyft), homebased drop-off and pick-up for multi-passenger service (e.g., microtransit), and meeting point multi-passenger service (e.g., Via).

\section{How does the service fare impact the ridership?}

Results show that ridership declines with increasing costs under all scenarios. As the AV service becomes more expensive, the riders will switch to driving alone rather than using the AV service to connect to transit. In general, ridership is highest for the shared door-to-door service (D2DRideshare), followed by shared rides with pick-up/drop-off (PUDO-Rideshare), and finally, for single passenger door-to-door service (D2D-Single). The use of all the service models drops

precipitously when the price is $\$ 2.50$ to $\$ 3$ per ride, and there is little demand when fares are greater than $\$ 5$ per ride.

\section{How do fares impact service quality?}

The travel time for users of the AV service is lower when the rides are less expensive. When the fare cost is zero or very low, the average travel time can be as low as 1,000 seconds or approximately 17 minutes. At high costs, travel times can be as high as one hour. At lower fare costs, there is a higher demand for the service. Thus, there are more vehicles in service areas actively looking to pick up and drop off passengers, which increases the efficiency of the vehicles and lowers the overall travel time for each rider.

The average wait time is about three minutes for the PUDO-Rideshare service and around five minutes for the D2D-Rideshare service, and it is relatively consistent across all price points for 
these shared services. In contrast, the wait time for the D2D-Single service varies significantly depending on the price point.

The detour ratio is the total distance traveled by the fleet divided by the sum of direct trip distances that all of the fleet passengers are taking. The results show that the D2D-Single service has a much higher detour ratio than the PUDO- or D2D-Rideshare services. A non-shared service causes a higher detour ratio because longer travel routes are needed to pick up each rider at their home. In contrast, the shared services have lower ratios because the total distance traveled by the vehicles is lower than the sum of the trip distances that the passengers traveled. In summary, the shared services are minimizing detours and reducing VMT, and the D2D single passenger services are increasing detours and VMT.

\section{How does the service fare impact VMT?}

For all scenarios, the service miles traveled decrease with increasing cost per ride. VMT is highest for the D2D-Single service, followed by the D2D-Rideshare and then by the PUDO-Rideshare service. The VMT of personal cars grows as the cost per ride goes up for all AV service models, and more people choose to drive instead of taking the AV service to the BART. Agencies looking to minimize VMT may consider using PUDOs over a D2D service.

\section{What is the revenue potential?}

The authors compare revenue derived from the automated taxis services to the costs of operating the automated taxis per mile. The operating costs have a lower estimate of $\$ 0.30 / \mathrm{mile}$ and high estimate of $\$ 0.50 /$ mile (2010 USD). See the figure 0 below.

The results show that the service revenue peaks at $\$ 3$ per ride for D2D-Rideshare (at around $\$ 200,000$ in daily revenue), at $\$ 3$ per ride for $\mathrm{D} 2 \mathrm{D}$-Single (at around $\$ 170,000$ ), and $\$ 2$ per ride for PUDO-Rideshare (at $\$ 100,000$ ). Thus $\$ 2-\$ 3$ per ride might be the "sweet spot" for revenue generation for this type of service based on the time and monetary costs of BART riders in the study area.

Overall, for both the high-cost and low-cost assumptions, profit is highest for the D2D-Rideshare service compared to the PUDO-Rideshare service and the D2D-Single service. The results for the high-cost scenario show that the D2D-Single service model never makes a profit while the ridesharing service sometimes makes a profit. 
Operating Costs and Revenue by Service Type and Fare
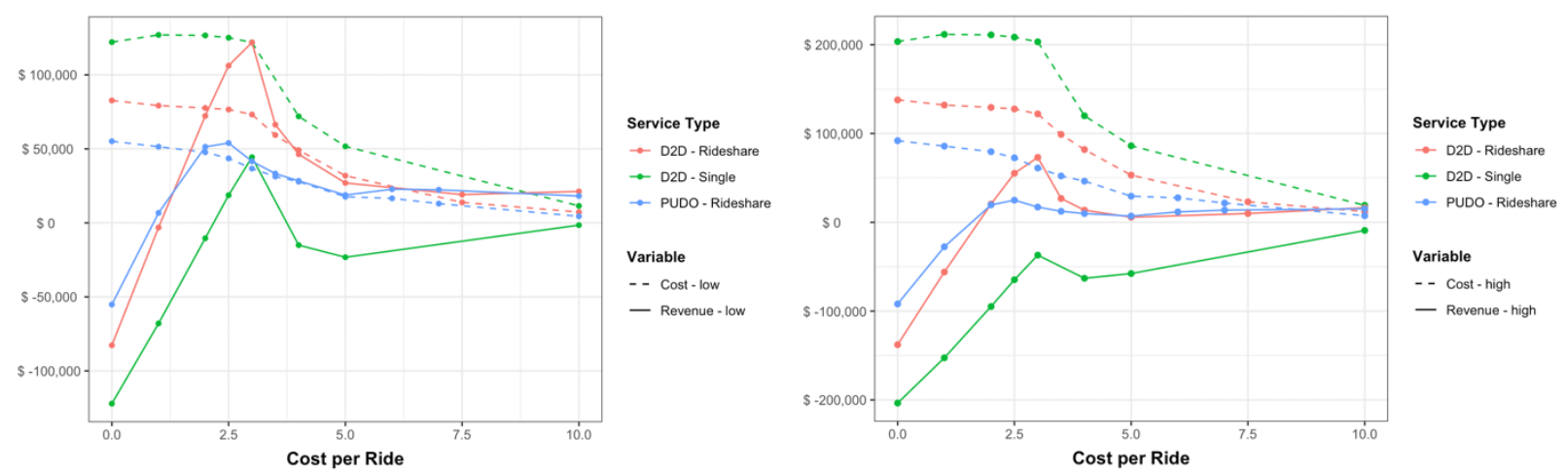


\section{Introduction}

Public transit typically operates using fixed routes and stops to maximize the efficiency of the service. However, studies show that travelers are generally not comfortable walking more than a quarter-mile to or from a public transit stop. This is called the first-mile, last mile mile problem, and it is a significant deterrent for potential transit riders, especially those residing in less dense, suburban neighborhoods. Transit agencies have typically sought to solve this problem by adding parking spaces near transit stations and adding stops to connect riders to fixed-route transit. However, this is often just a short-term solution since parking space is limited and will fill up with commuters before other riders can utilize those spaces. Also, parking lots and structures can be expensive to construct, and transit agencies could use this valuable land for other purposes, like transit-oriented development, that could also generate significant transit ridership. Restricted access to transit undermines transit revenue and increases congestion and greenhouse gas emissions (GHGs).

New mobility services such as ridehailing, ridesharing, and microtransit may offer fast, reliable connections to and from transit stations. In the last few years, transit agencies have piloted many projects throughout the United States to test this concept. However, there is limited research that evaluates the potential impacts of these projects. Furthermore, there is growing interest in the future of automated vehicles (AVs) and these vehicles' potential to solve the first-mile problem by reducing the cost of providing these new mobility services to access transit.

This paper expands upon existing research to simulate and model the potential impacts of automated microtransit vehicles on transit use (i.e., Bay Area Rapid Transit or BART) in the San Francisco Bay Area. This paper uses the San Francisco Bay Area MATSim model (BAMATSim), which uses activity data and other parameters from the region's official activity-based travel model. The BA-MATSim was developed at the Institute of Transportation Studies, University of California, Davis. In this paper, the agent-based model simulates door-to-BART ridehailing and ridesharing and meeting point ridesharing services with AVs at different price points. ${ }^{1}$ The analysis includes a cost-benefit analysis to evaluate whether the AV operator in the simulation will recoup their costs. 


\section{Literature Review}

\subsection{Modeling First-/Last-Mile Services}

As ridehailing and ridesharing services have grown in popularity, researchers have highlighted the opportunity to use these services to address the first-/last-mile problem. ${ }^{2}$ Transportation agencies are also turning to microtransit, an on-demand transit service that acts as a feeder system for larger regional fixed-route transit systems. This section will review studies that explore the potential of ridehailing, ridesharing, and microtransit services to improve transit access for riders.

Two studies focus on investigating travel behavior from the demand side. Shepherd and Muir (2011) used an individual behavior model, MARS, in a program called "CityMobil" to elaborate on how feeder systems impact the existing public transit network. ${ }^{3}$ They found that feeder systems reduce access and wait times and increase public transport share in both peak and off-peak hours. The impacts are more pronounced for zones with initially poor access or egress to mainline public transport. Martinez and Viegas (2017) investigated travel behavior using a nested logit mode choice model to predict mode shares. ${ }^{4}$ They examined what would happen if automated taxis and advance-scheduled automated shuttles were to replace both private vehicle trips and current bus trips. With a massive mode shift, the transportation system would see a $34 \%$ reduction in carbon dioxide emissions. Wait times would be limited to 5 minutes for automated taxis and 10 minutes for automated shuttles, and costs would be affordable at about $\$ 0.32$ per kilometer.

One study, conducted by Stiglic et al. (2018), focused on the optimization of the ride-matching problem. ${ }^{5}$ Those researchers conducted an extensive numerical study on a hypothetical network, including two commuter train lines and four urban rapid transit lines. Results show that the integrated system could increase the average number of matched riders and reduce the average length of the driver detour. Reducing total system-wide vehicle miles traveled (VMT) may also reduce emissions and congestion. The study also showed that there would be greater benefits if a driver shared the ride with more than one passenger.

A further two studies used an integer programming model to optimize the integrated system focus specifically on the transit access problem. ${ }^{6}$ Maheo et al. (2017) proposed an efficient solving method based on a mixed-integer programming model, aiming at the optimal design of a feeder system with human-driven taxis feeding into high-frequency bus lines. ${ }^{7}$ They found that the optimized system could decrease transit wait times, minimize costs, and maximize convenience compared with the existing bus system. Instead of human-driven taxis, Liang et al. (2016) provided two integer programming models for optimizing an automated taxi system for last-mile service to train stations. ${ }^{8}$ In one model, automated taxis can choose requests to serve, and in the other, automated taxis satisfies any reservation in a selected zone. Results show that zone location and trip selection (second model) can diminish the negative impact of imbalances in the supply of taxis, which contributes to the daily profit. 
Meanwhile, agent-based simulation has recently become popular in AV research for its advantages in capturing individual behaviors, enabling dynamic operations, and accounting for stochasticity. ${ }^{9}$ Three papers provide insight into the system performance and the potential of ridesharing to enhance mobility and to improve public transport access. ${ }^{10}$

In the first, Basu et al. (2018) presented a multi-modal activity-driven agent-based simulation approach to investigate the impact of automated mobility on demand (AMoD) on urban mobility. ${ }^{11}$ The model shows that transit ridership increased with the introduction of $\mathrm{AMoD}$ targeting first- and last-mile connectivity. The agent-based simulation model is also employed to examine how new shared mobility services could change mobility in the Greater Dublin Area. In that paper, the author chose to investigate two shared transport services: shared taxi (an ondemand door-to-door service) and taxi-bus (which moves along dynamically optimized routes between designated stops). ${ }^{12}$ The author revealed that the integration of new shared mobility services with existing public transport not only creates greater flexibility for users but also enhances the performance of public transport services and infrastructure.

In the second, Shen et al. (2018) also used agent-based simulation to simulate an integrated automated vehicle and public transportation $(\mathrm{AV}+\mathrm{PT})$ system. ${ }^{13}$ Results indicate that the integrated system has the potential to enhance service quality, occupy fewer road resources, achieve financial sustainability, and utilize bus services more efficiently.

In the third, Wen et al. (2018) proposed a simulation-based approach to the design and evaluation of integrated $\mathrm{AV}+\mathrm{PT}$ systems. ${ }^{14}$ The simulated experiments show that encouraging ridesharing, allowing requests in advance, and fare integration with transit help enable service integration and sustainable travel.

In summary, studies have demonstrated the potential of ridehailing, ridesharing, and microtransit to serve as the first-mile transit access solution. However, most of the studies set the cost of service at a single value based on different assumptions. None of them investigated the system at different price points and using different service models. Hence, in this research, the authors model ridehailing, ridesharing, and microtransit services with different pricing. 


\subsection{Fare Costs For First-/Last-Mile Services}

Pilot programs have been implemented in cities across the United States to address the first- and last- mile problem with door-to-door shared microtransit (e.g., vans, buses), ridehailing companies (e.g., Uber and Lyft), and shared-ride operators with dynamic pick-up locations (e.g., Via and Chariot). Although these pilots do not employ autonomous vehicles, the authors used their fare policies as a reference for the simulations in this study.

Table 1 summarizes 23 pilot programs that connect ridehailing, ridesharing, or microtransit services with public transit around the United States, 11 of which are currently active. The service type is classified as follows: single passenger door-to-door (D2D-Single), shared-door-to-door (D2D-Ridesharing), and shared with pick-up/drop-off point (PUDO-Ridesharing). Most D2D programs have partnerships with transportation network companies (TNCs), such as Uber and Lyft, and discounts are applied when taking these ridehailing and ridesharing vehicles to transit stations and stops. PUDO-Ridesharing operators, such as the Chariot and Via Mobility services, tend to operate larger vehicles and provide free or low-cost (\$4 or less) trips for passengers.

All 23 programs involve monetary expenditures by government or quasi-government entities to provide travelers with free, low-price, or discounted first-/last-mile service. For those with a fixed rate (including free trips), the regular fare is always below $\$ 4$ per ride. For those discounted trips, total fare reductions depend on the travel distance and travel time. 
Table 1. Fares of First- and Last-Mile Pilot Programs in the United States

\begin{tabular}{|c|c|c|c|c|}
\hline \multirow[t]{2}{*}{ Service Type } & \multirow[t]{2}{*}{ Company } & \multicolumn{3}{|c|}{ Fare per Ride } \\
\hline & & Free & $\$ 4$ and Less & Discounted \\
\hline \multirow[t]{3}{*}{$\begin{array}{l}\text { Single Door-to-Door } \\
\text { (D2D-Single) }\end{array}$} & Uber & & Pinellas, FL & $\begin{array}{c}\text { Altamonte Springs, FL* } \\
\text { (25\% off) } \\
\text { San Joaquin, CA } \\
\text { (50\% off, up to } \$ 5 \text { ) } \\
\text { Philadelphia, } \mathrm{PA}^{*} \\
\text { (40\% off, up to } \$ 10)\end{array}$ \\
\hline & Lyft & $\begin{array}{c}\text { Tacoma, WA } \\
\text { (48 rides/month) }\end{array}$ & $\begin{array}{l}\text { Vallejo, } \mathrm{CA}^{*} \\
\text { Summit, NJ* } \\
\text { (2 rides/day) }\end{array}$ & $\begin{array}{l}\text { Las Vegas, NV* (\$1 off) } \\
\text { Charlotte, NC (\$4 off) } \\
\text { Phoenix, AZ* (20\% off) }\end{array}$ \\
\hline & Others & & Pinellas, FL & \\
\hline \multirow{3}{*}{$\begin{array}{l}\text { Door-to-Door } \\
\text { Rideshare } \\
\text { (D2D-Rideshare) }\end{array}$} & Uber & $\begin{array}{l}\text { Dallas, TX } \\
\text { (2 rides/day) }\end{array}$ & & \\
\hline & Lyft & Centennial, $\mathrm{CO}^{*}$ & Monrovia, CA & Marin, $\mathrm{CA}^{*}$ (up to $\$ 5$ ) \\
\hline & Others & $\begin{array}{l}\text { San Joaquin, CA } \\
\text { Tampa, FL* } \\
\text { (first } 5 \text { rides) }\end{array}$ & Tampa, FL* & \\
\hline \multirow[t]{3}{*}{$\begin{array}{l}\text { Pick-up Drop-off } \\
\text { Points Rideshare } \\
\text { (PUDO-Rideshare) }\end{array}$} & VIA & Los Angeles, CA & $\begin{array}{l}\text { Los Angeles, CA } \\
\text { Southeast Seattle and } \\
\text { Tukwila, WA }\end{array}$ & \\
\hline & Chariot & $\begin{array}{c}\text { King, WA } \\
\text { West Seattle, WA }\end{array}$ & $\begin{array}{c}\text { King, WA } \\
\text { West Seattle, WA }\end{array}$ & \\
\hline & Others & & $\begin{array}{c}\text { North San Jose, CA* } \\
\text { Newark and Castro Valley, } \\
\text { CA }\end{array}$ & \\
\hline
\end{tabular}

\subsection{Costs for Automated Vehicles}

The research team also reviewed the potential operating and capital costs of automated vehicles to evaluate the costs and benefits of AV first-/last-mile service. The total costs for automated vehicles can be categorized into capital (fixed) costs and operating (variable) costs. Fixed costs are initial investments or fixed-term expenses, such as financing, depreciation, insurance, registration fees, and scheduled maintenance. Variable costs are operating expenses, such as fuel, tire wear, paid parking, and crash costs. Many studies have estimated the cost structures and built cost-based models of AVs. The validity of those estimations and conclusions relies heavily on assumptions about the values. 
Burns et al. (2013) calculated the fixed and variable costs per trip of shared AVs (medium sedans) in three contexts: small to medium town, suburban, and urban. ${ }^{15}$ The result shows that the shared AV service could provide lower-cost trips compared to the existing transport services. In a small to medium town, the cost is only $\$ 0.15$ per trip-mile. Stephens et al. (2016) showed that the potential range of the costs for fully connected and automated vehicles (CAVs) used with ridesharing could be $\$ 0.20-\$ 0.30$ per passenger-mile. ${ }^{16}$

Another study conducted by Fagnant and Kockelman (2015) focused on possible prices for users of a centrally organized, shared AV system. ${ }^{17}$ They assumed an investment cost of $\$ 70,000$ and operating costs of $\$ 0.50$ per mile, finding that a fare of $\$ 1.00$ per trip-mile for an AV taxi could still be profitable. Building on their work, Johnson (2015) wrote in a research report, "by removing the driver from the equation (the largest cost in a taxi ride), the average cost per mile to the consumer could be 44 cents for a private ride in a standard sedan and 8 cents for a shared ride in a two-seater." ${ }^{18}$ This would be lower than the price consumers now pay to ride in an UberX car (\$3$\$ 3.50$ per mile) or an UberPool vehicle (\$1- $\$ 1.50$ per mile).

Further studies presented more comprehensive ways to estimate operating costs for future automated vehicles by taking into consideration overlooked costs like cleaning. ${ }^{19}$ Litman (2017) believed there would be an extra $\$ 0.50-1.00$ per trip, or $\$ 0.05-\$ 0.10$ per vehicle-mile when he included a $\$ 5-10$ cost for cleaning. ${ }^{20}$ Bösch et al. (2018) showed that cleaning costs might play the most important role in the success of shared AV fleets because they are the largest contribution to the operating costs, even with low cleaning frequencies and costs. ${ }^{21}$

Some manufacturers and consulting firms have estimated future costs for automated vehicle fleets based on current technology and associated costs. Table 2 displays a preliminary list of estimates of future costs published in 2016. The estimated future costs could be as little as $\$ 0.29 / \mathrm{mile}$ (Barclays) to as much as a dollar per mile (Ford). It is difficult to compare the estimates because they make different assumptions and forecast costs for different future years. However, a rough conclusion indicates that in the next two decades, the costs for automated vehicle fleets could be around $\$ 0.30 /$ mile to $\$ 0.50 /$ mile. 
Table 2. Estimates of Future Costs of Automated Vehicles

\begin{tabular}{lll}
\hline Institute & Current Costs (USD per mile) & Future Costs (USD per mile) \\
Ford & $\$ 0.84$ & $\$ 1.00$ by 2021 \\
Rocky Mountain Institute & $\$ 0.51$ by 2025 \\
& & $\$ 0.33$ by 2035 \\
Morgan Stanley & $\$ 0.50$ by 2030 \\
KPMG & $\$ 0.82$ & $\$ 0.43$ \\
Deloitte & $\$ 0.31-\$ 0.46$ \\
Barclays & $\$ 0.29$ by 2040 \\
\hline
\end{tabular}




\section{Methodology}

\subsection{Model Description}

The San Francisco Bay Area activity-based travel model (MTC-ABM) simulates the travel-related choices of Bay Area residents. The model uses data from the Metropolitan Transportation Commission's (MTC) 2000 Bay Area Travel Behavior Survey, which included two-day travel diaries from 15,000 households. In the model, tours are the unit of analysis. A tour represents a closed or half-closed chain of trips starting and ending at home or the workplace; a tour includes at least one destination and at least two successive trips. Like all other activity-based models, the model generates tour and trip lists for each individual. The individual and joint trips are later aggregated into origin/destination matrices and assigned to the network by mode and time of the day. In the process, there is no way to link traveler attributes with the vehicles or modes they occupy.

To understand how drivers' perceptions of time and monetary costs could change their behavior, the authors integrated the MATSim model with the MTC-ABM. MATSim uses detailed travel activity patterns for large-scale regional simulations. To avoid long computational times, MATSim uses a spatial queue model, rather than simulating car-following and lane-changing details; this yields significantly faster computational speeds, making the MATSim framework practical for regional applications.

The research team developed Python scripts to automate the conversion of the MTC network and trip list (travel activity by person/household attribute) to the format required by MATSim. The conversion of the trips list required the refinement of trip departure time by hours to minutes. ${ }^{22}$

The authors then used data from the 2000 Bay Area Transportation Survey to estimate the distribution of trip departure time by 15 -minute intervals by hour within each time period and by county. Trips within each hour from the model were then randomly selected and then assigned departure times within the hour based on weighting factors developed from this distribution. ${ }^{23}$

The value of time for each individual is in the trip list. These values are available from the MTC$\mathrm{ABM}$, and the data are from a stated preference survey conducted in the San Francisco Bay Area. The value of time in the model is log-normally distributed and segmented by four income groups (low, medium, high, and very high). This variable, the value of time, is key to estimating the generalized cost function for each person. ${ }^{24}$

\subsection{Matsim Mode Choice Model}

The current study benefits from recent improvements in the BA-MATSim model, including the addition of demand-responsive transit access with and without automated vehicles. The authors implemented this new model to simulate the demand for the following transit access services with 
AVs: (1) Door-to-door (D2D-Single), a single-passenger ridehailing service; (2) Door-to-door (D2D-Ridesharing), whereby eight-seat vehicles provide a home-based pick-up ridesharing service; and (3) Pick-up and Drop-off Points (PUDO), whereby the same eight-seat vehicles provide a ridesharing service that picks up riders who walk to the service collection point from their home.

BA-MATSim model handles vehicle dispatch for the transit access services by using a fleetwide optimization approach. On the passenger side, an agent calls for a vehicle the moment the passenger wishes to depart. The vehicle assignment then takes place based on insertion heuristics. Service criteria can be specified to limit the length of detours in a ridesharing vehicle. These criteria include (1) a maximum travel time, which is defined by a trip-specific detour (as a factor of the direct travel time) plus a constant, and (2) a maximum waiting time. If no vehicle is available for dispatch, then the ride request is denied..$^{25}$

MATSim comes with a module that simulates the effects of larger automated taxi fleets within reasonable computational times. The dispatch algorithm follows a simple but efficient heuristic, which can be described by two states depending on the amount of demand. First, in times of oversupply (i.e., during off-peak periods), the closest vehicle is dispatched for a new ride request. Second, in times of undersupply, a vehicle, once it is available, is dispatched to the closest waiting request, which may lead to longer wait times for people sending requests from remote locations, but it leads to efficient fleet utilization. The model also tracks empty AV travel. For this model, the research team created 5,000 vehicles that start their day randomly throughout the model area.

In combination with mode choice, the authors applied different pricing to the automated taxis (from $\$ 0$ to $\$ 10 /$ ride). The research team based this range on a review of existing prices for microtransit services. Then, the authors compared the revenue derived from the automated taxis to the costs of operating the automated taxis per mile. The research team used an estimated range of costs from $\$ 0.30$ to $\$ 0.50$ per mile and compared this range to the revenue to evaluate whether the AV operator in the simulation will recoup their costs.

To identify the pick-up and drop-off (PUDO) locations, the team developed a simulationoptimization framework to evaluate first-mile transit access programs using shared mobility services. The framework uses results from MTC-ABM scenarios as inputs of a customized optimization model based on spatial approximation methods. The approximation model finds the number and approximate location of PUDOs that minimize accessibility (walking times to PUDO), waiting times (at PUDO for vehicle arrival, or other trip passengers), and in-vehicle time to the transit station (BART). From MTC-ABM, the team identified individuals who could switch from single-occupancy vehicles to the shared mobility/transit service for work trips by identifying those individuals who could feasibly take transit to their work destination but do not. 


\section{Results}

The authors compare the different scenarios using the three different service models (D2D-Single, D2D-Rideshare, and PUDO-Rideshare) over a range of per-ride costs from $\$ 0$ to $\$ 10$ in 2010 USD. The simulations include the morning peak period during an average weekday.

First, consider ridership. Figure 1 shows that ridership declines with increasing cost; riders are deciding between using the AV service to connect to BART or driving alone, based on their time and monetary costs. As the AV service gets more expensive, riders will switch to driving alone rather than using the $\mathrm{AV}$ service to connect to transit.

Figure 1. Service Rides by Type and Fare

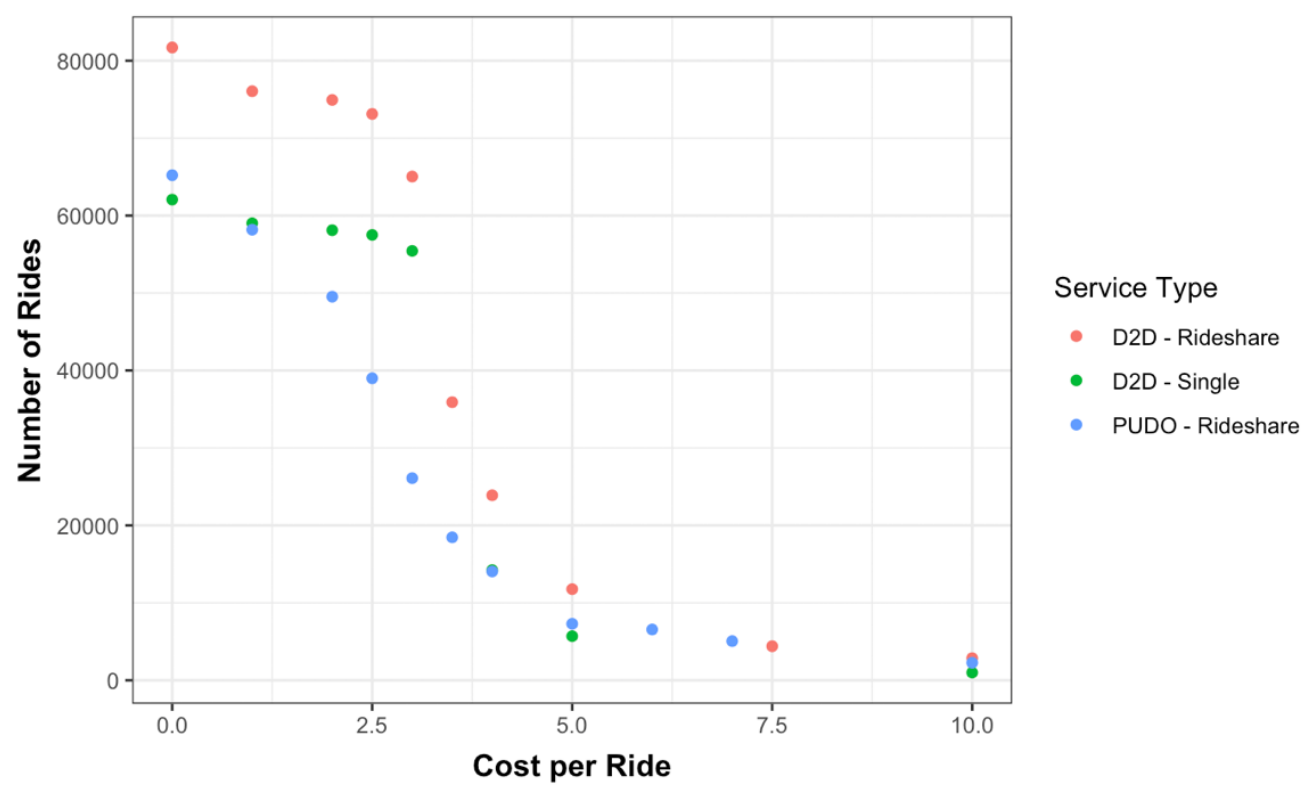

In general, ridership is highest for D2D-Rideshare, followed by PUDO-Rideshare, and finally, by D2D-Single. The use of all the service models drops precipitously at $\$ 2.50$ to $\$ 3$ per ride, and there is little demand when fares are greater than $\$ 5$ per ride.

Figure 2 shows that the AV service is faster (i.e., lower travel time for users) when the rides are less expensive. One reason is that at lower costs, there is a higher demand for the service. Thus, there are more vehicles in service areas actively looking to pick up and drop off passengers, which increases the efficiency of the vehicles and lowers the overall travel time for each rider. When the fare cost is zero or very low, the average travel time can be as low as 1,000 seconds or approximately 17 minutes. At high costs, travel times can be as high as one hour. 
Figure 2. Average Travel Time (seconds) by Service Type and Fare

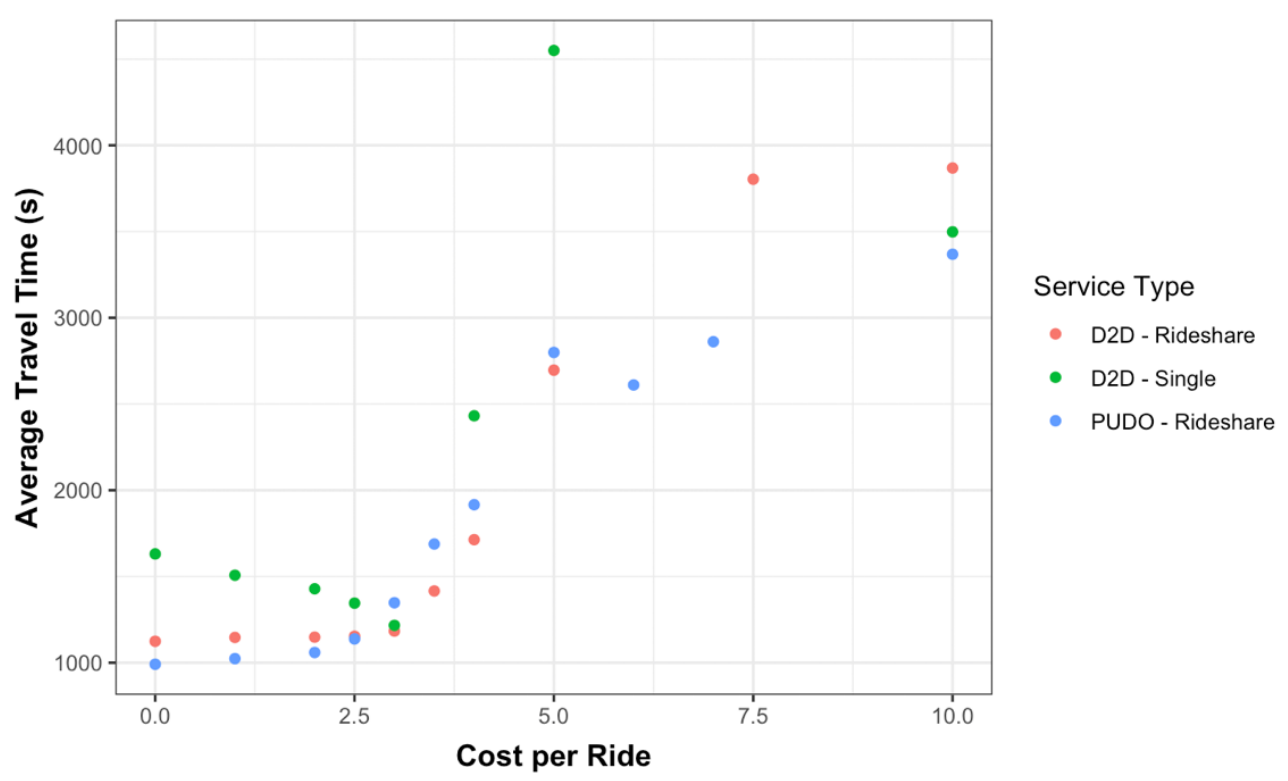

The average wait time is about three minutes for the PUDO-Rideshare service and around five minutes for the D2D-Rideshare service; it is relatively consistent across all price points for these shared services. In contrast, the wait time for the D2D-Single service varies significantly depending on the price point. The meeting locations for the PUDO service mean riders' wait times are shorter for this service relative to the D2D services. When D2D-Single is free, and there is a high demand, then wait times are longer. The opposite is also true; when D2D-Single is costly, demand and wait times are low. 
Figure 3. Average Wait Time per Passenger (in seconds) by Service Type and Fare

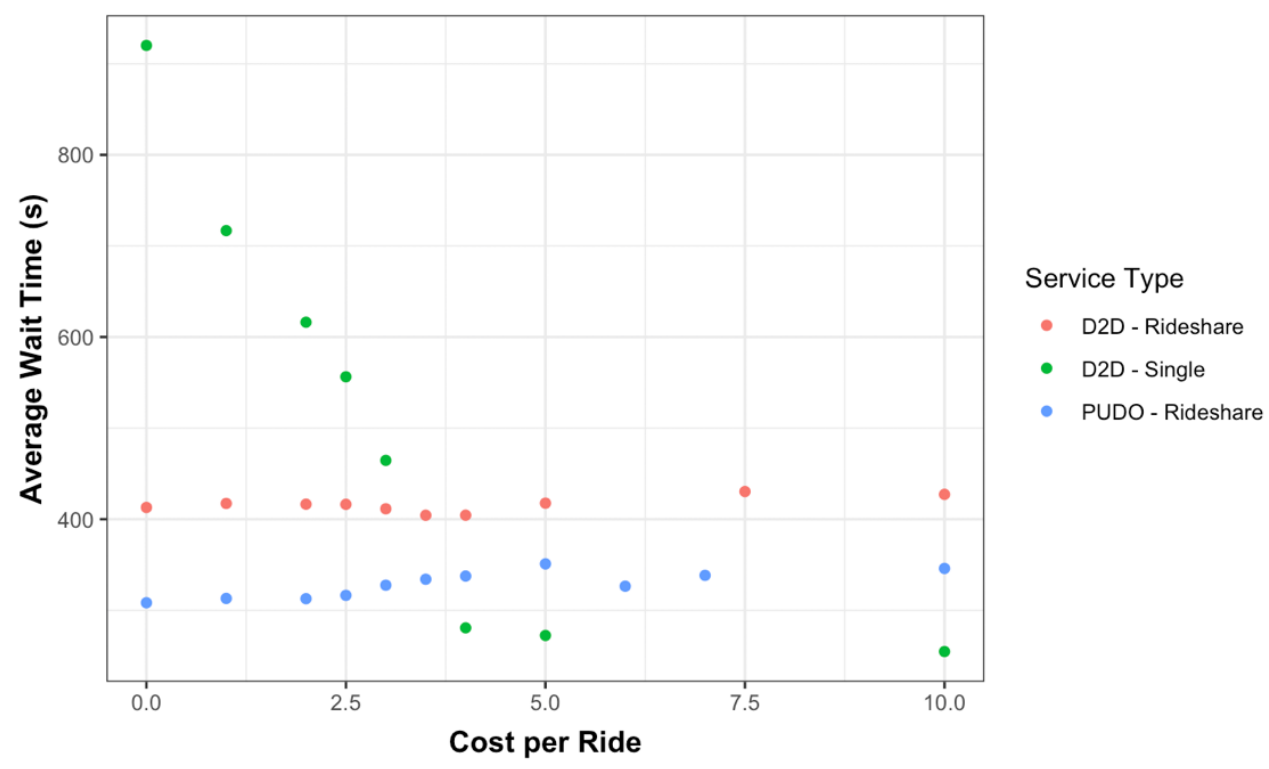

Figure 4 shows the lambda or detour ratio for each of the scenarios. The detour ratio is the total distance traveled by the fleet divided by the sum of direct trip distances taken by all of fleet passengers. The figure shows that the D2D-Single service has a much higher detour ratio than the PUDO- or D2D-Rideshare services. As expected, a non-shared service causes a higher detour ratio because longer travel routes are needed to pick up each rider at their home. In contrast, the two shared services have ratios lower than 1 , which shows their efficiency, since the total distance traveled by the vehicles is lower than the sum of the trip distances that the passengers traveled. In summary, the shared services are minimizing detours and reducing VMT, and the D2D single passenger services are increasing detours and VMT. 
Figure 4. Lambda (detour ratio) by Service Type and Fare

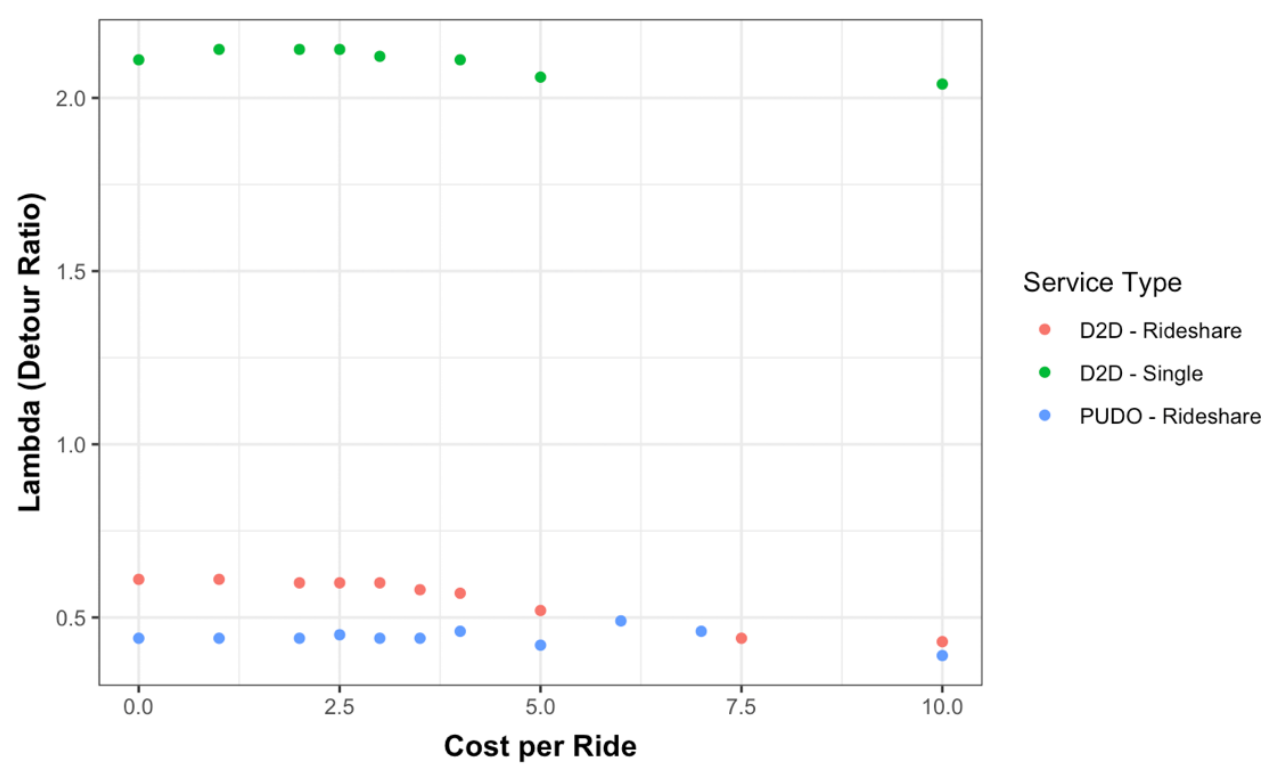

Figure 5. The Number of Miles Traveled by Servie Type and Fare

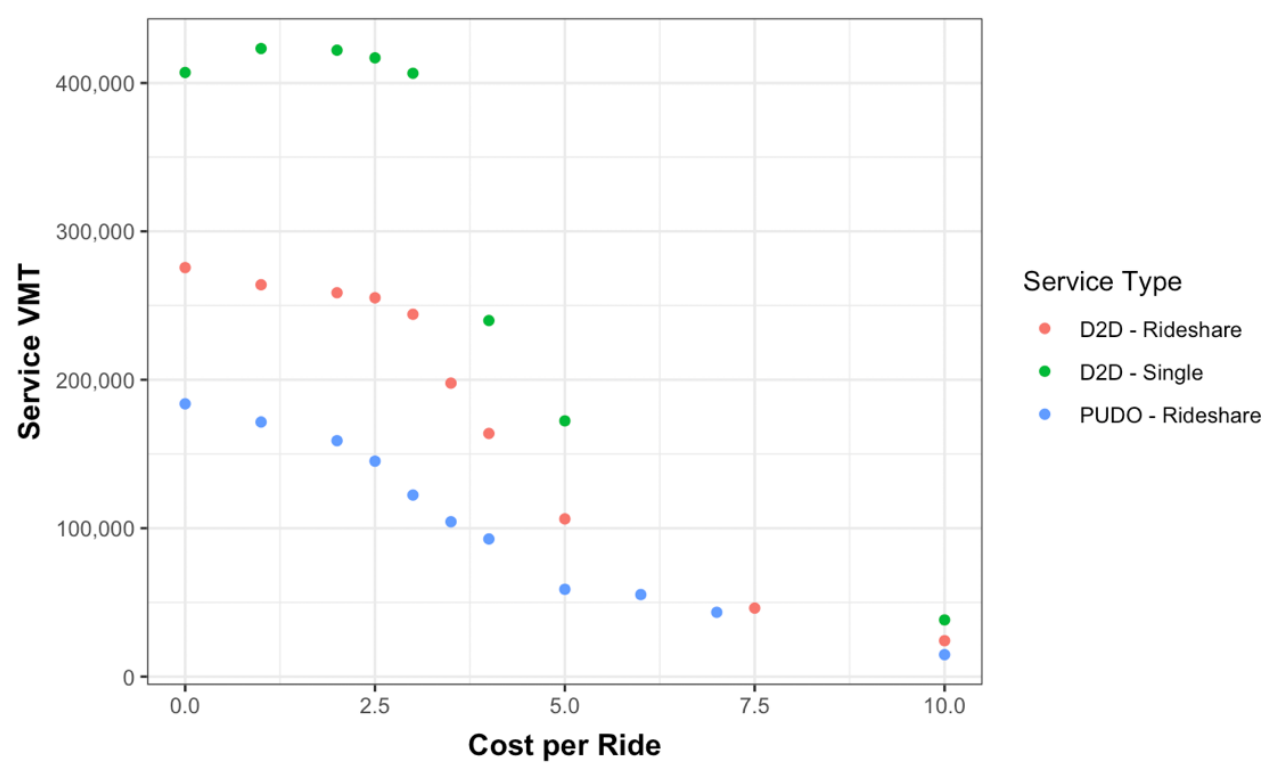

Figure 5 shows the number of miles traveled by the AV fleet for each scenario. Service miles traveled are highest for D2D-Single, followed by D2D-Rideshare, and they are lowest for the PUDO-Rideshare service. This trend can also be seen in Figure 6, which shows the number of 
zero passenger miles for each scenario. The value of zero passenger miles indicates the number of miles traveled by the fleet of AVs with no passengers.

Figure 6. Zero Passenger Miles Traveled (i.e., number of miles traveled by the AVs with no passengers) for Each Scenario

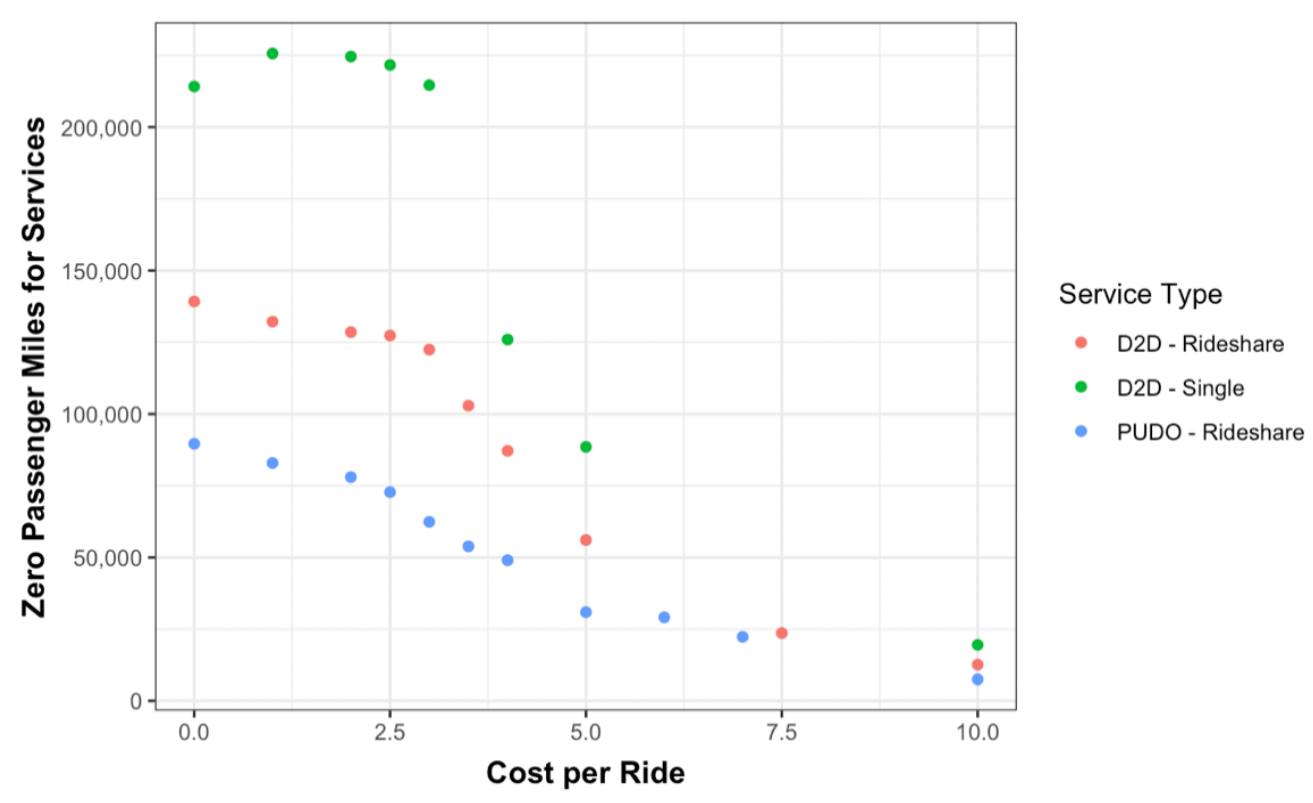

Figure 7 shows the total miles traveled by transit users who use a personal vehicle to access a BART station. In the model, the transit rider chooses one of the new service types or drives in a car. As expected, the VMT of personal cars grows as the cost per ride goes up for all AV service models, and more people choose to drive instead of taking the AV service to the BART. The VMT of personal cars stays relatively high in the scenario for D2D-Single. 
Figure 7. Vehicle Miles Traveled by Personal Vehicle by Service Type and Fare

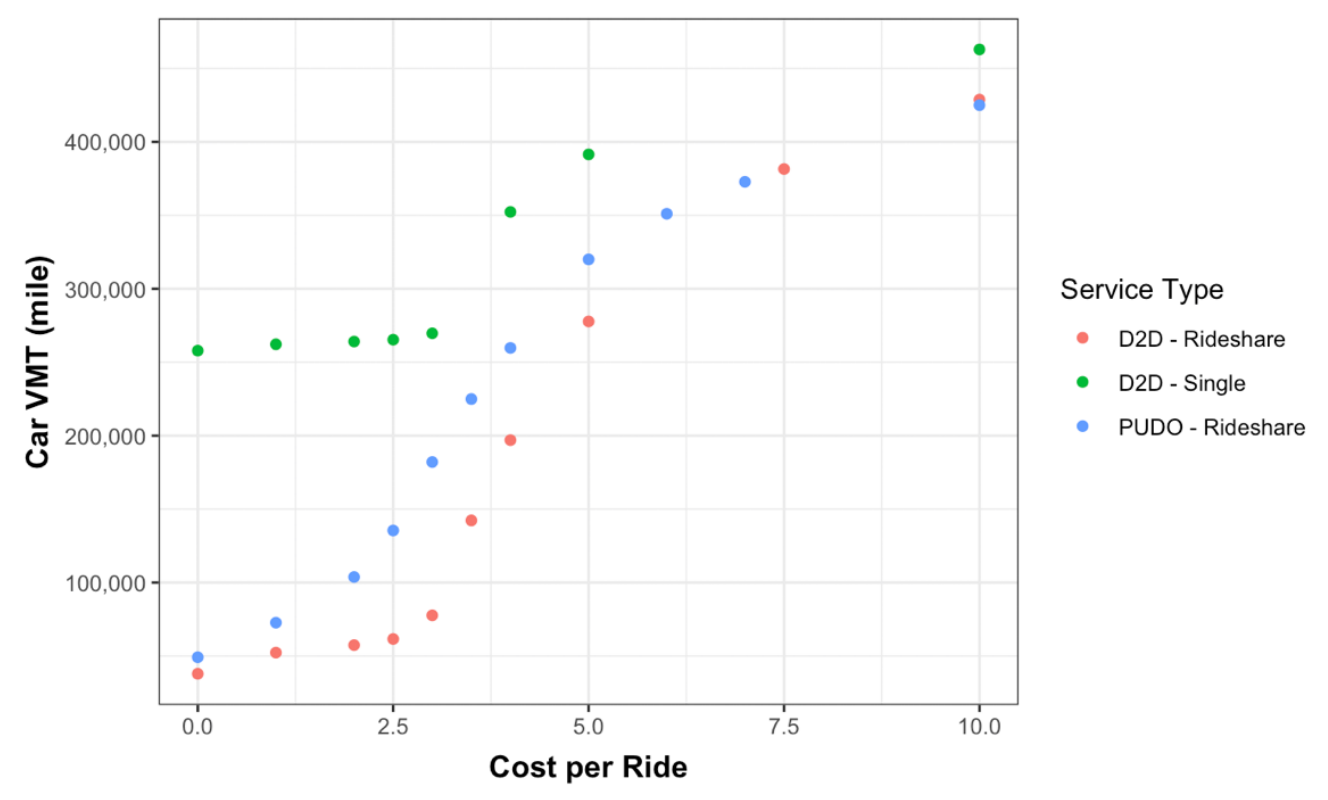

Figure 8 shows the total VMT, which includes VMT for personal vehicles and the new mobility services used to access BART stations, in each scenario. The PUDO service provides the most significant overall reduction in VMT when its fare is lower than $\$ 2.50$ per ride. The D2D-Single service creates additional VMT compared to the D2D-Rideshare or PUDO-Rideshare services. At low fare costs, the PUDO service model has lower VMT than the D2D-Rideshare service model. Agencies looking to minimize VMT may consider using PUDOs over a D2D service. 
Figure 8. Total Distance Traveled by Service Type and Fare

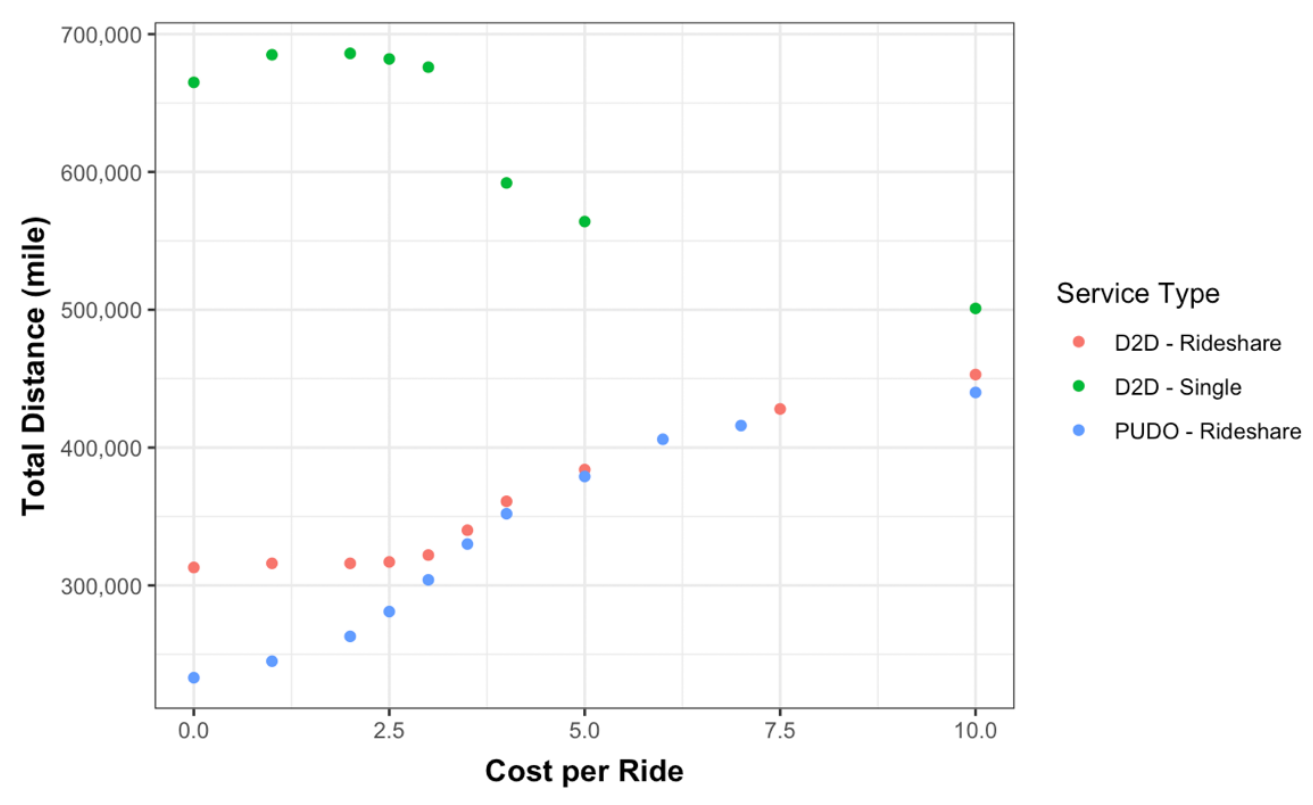

Figure 9 shows the service revenue for each scenario calculated by multiplying the number of rides by the service's fare. Revenue peaks at $\$ 3$ per ride for the D2D-Rideshare service (at around $\$ 200,000$ in revenue per day); $\$ 3$ per ride for $\mathrm{D} 2 \mathrm{D}$-Single (at around $\$ 170,000$ ); and $\$ 2$ per ride for PUDO-Rideshare (at $\$ 100,000$ ). These results suggest that $\$ 2$ to $\$ 3$ per ride might be the "sweet spot" for revenue generation for this type of service based on the time and monetary costs of BART riders in the study area. 
Figure 9. Total Revenue by Service Type and Fare

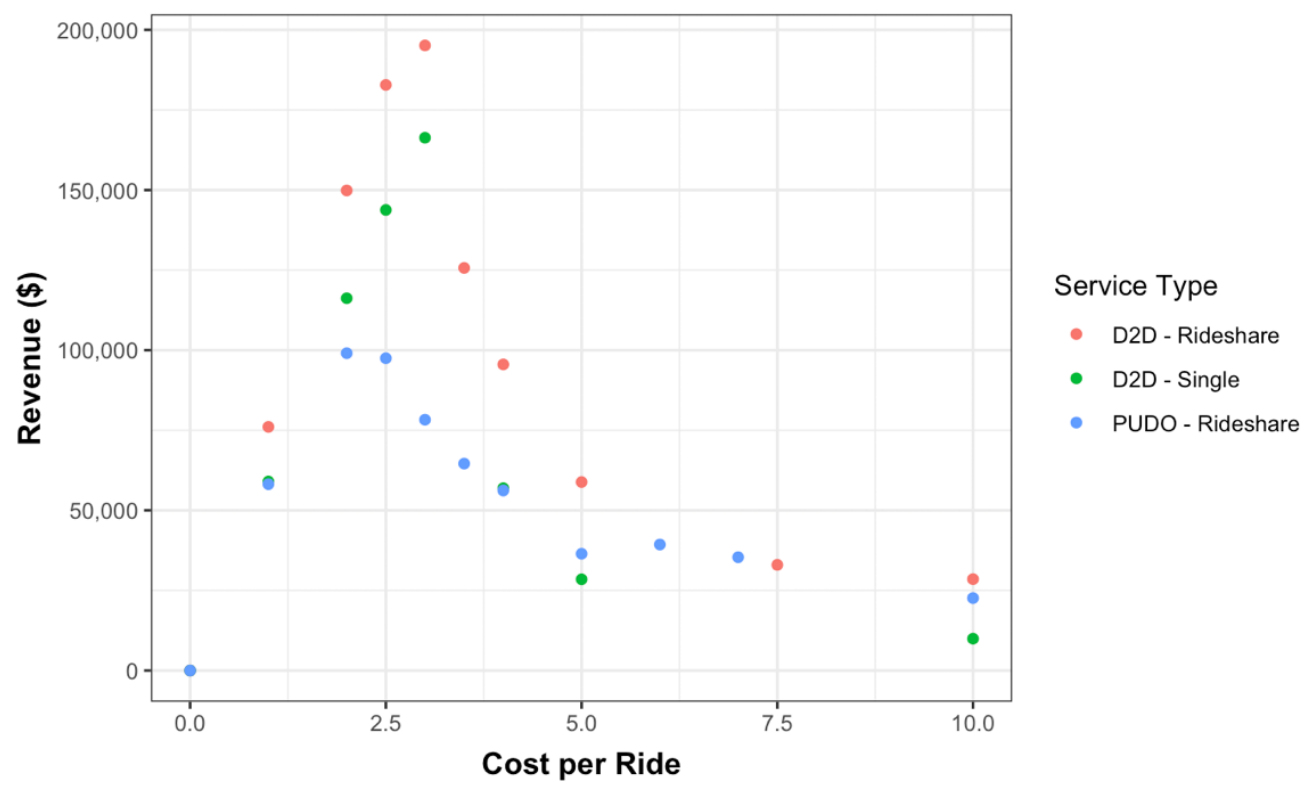

To calculate the cost of operating the services with an AV fleet, the authors used a low and high estimate of the per-mile cost for operating AV fleets from the literature review above. The authors estimate the low cost to be $\$ 0.30 / \mathrm{mile}$ and the high cost to be $\$ 0.50 / \mathrm{mile}$.

The operating costs of the AVs are the product of the total number of miles traveled in an AV by cost per mile. As shown in Figure 10 and Figure 11, profit is highest for the D2D-Rideshare service compared to the PUDO-Rideshare service and the D2D-Single service. At low costs, all services profit at some point; however, D2D-Rideshare performs best, followed by PUDORideshare, and last is D2D-Single. When costs are high, D2D-Single does not make a profit at any point, while D2D-Rideshare and PUDO-Rideshare sometimes make a profit. 
Figure 10. Low Operating Costs and Revenue by Service Type and Fare

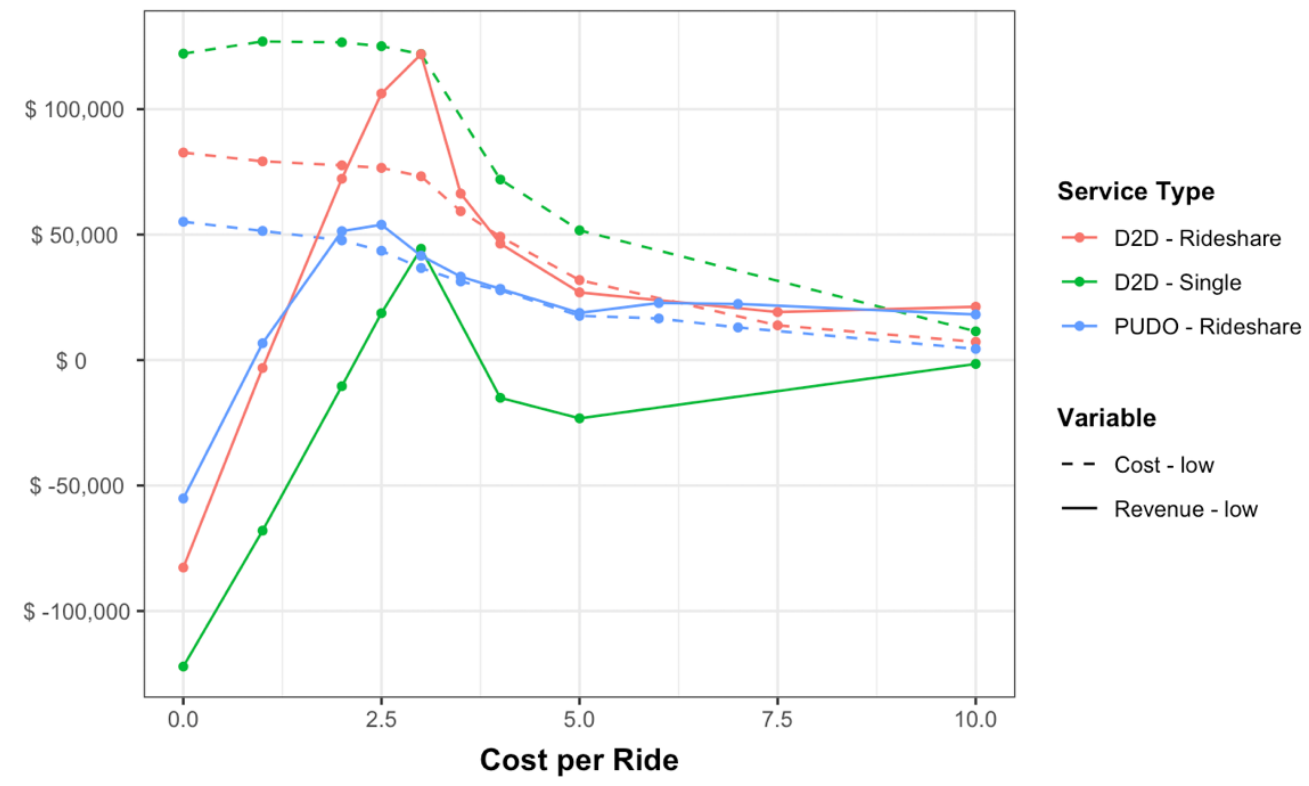

Figure 11. High Operating Costs and Revenue by Service Type and Fare

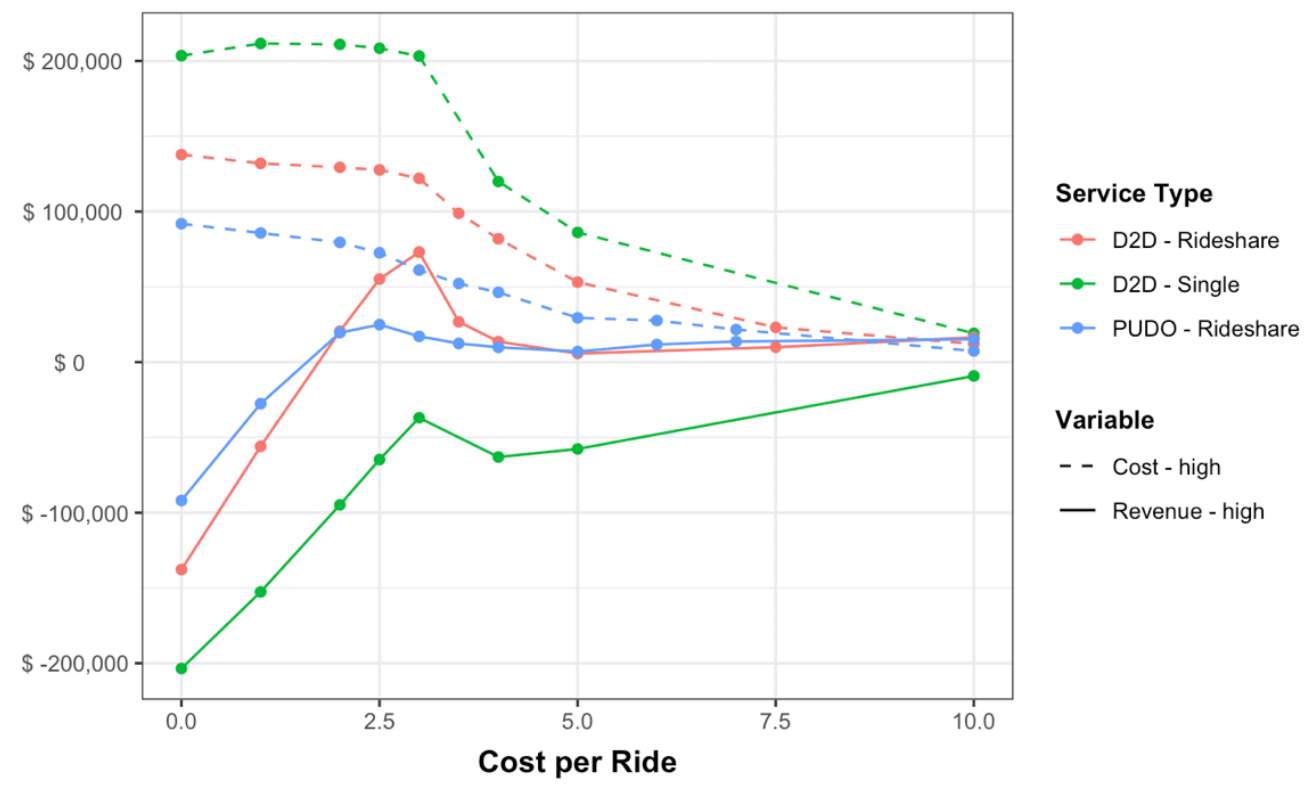




\section{Conclusions}

In this study, the San Francisco Bay Area MATSim model (BA-MATSim) simulates an AV fleet that offers first-mile access to transit at different price points for three different service models, which include door-to-door ridehailing and ridesharing and meeting point ridesharing services. Furthermore, the authors conducted a cost-benefit analysis to evaluate whether the AV operator in the simulation will recoup their costs. Key findings from the study follow.

AVs employed as a transit access service may increase ridership and reduce VMT. When the cost per ride is low, the VMT of personal cars is small for all AV service models, and more people choose to take the AV service to the BART instead of driving personal cars.

Pooled AV access services minimize VMT and zero passenger miles. Under the same conditions, both the service VMT and zero passenger miles for the PUDO-Rideshare and D2D-Rideshare service models are lower than those for the D2D-Single service model. Meanwhile, the total distances for single rider models are higher compared to the pooled service models. The D2DSingle service also has a much higher lambda detour than the PUDO or D2D services. The pooled services are minimizing detours and reducing VMT, and the D2D single passenger services are increasing detours and VMT.

Pooled services are arguably more efficient, especially when a pick-up/drop-off model is chosen rather than a door-to-door model. As mentioned above, the two shared services (PUDO- and D2D-Rideshare) have lower lambda detour ratios than the D2D-Single service, which means they are more efficient. Moreover, the average wait time for the PUDO-Rideshare service is lower than for the D2D-Rideshare service. Overall, a pick-up/drop-off model is more efficient than a doorto-door model with respect to the detour ratio and the wait time.

Pooled service models may be more likely to create profits, while single rider models struggle to keep out of the red. Profit is highest for the D2D-Rideshare service compared to the PUDORideshare service and the D2D-Single service. At higher cost estimates, the profit for the D2DSingle service model is never positive; it is positive only for D2D-Rideshare.

Fares will have to be low to incentivize ridership. Ridership is high when fares are less than $\$ 5.90$ (2020 USD). The use of all the service models drops when fares cost $\$ 2.95$ to $\$ 3.54$ per ride, and there is little demand when fares are greater than $\$ 5.90$ per ride. The estimated lower operation costs for automated vehicles may enable lower fares.

In sum, pooled first-mile, last-mile transit access services reduce VMT and travel time and increase revenues compared to the single-passenger service; however, fares all services need to be kept relatively low to attract riders. 


\section{Acronyms and Abbreviations}

$\mathrm{AMoD}$

AV

$\mathrm{AV}+\mathrm{PT}$

BA-MATSim

BART

CAV

D2D-Single

D2D-Ridesharing

GHGs

MTC

MTC-ABM

PUDO-Ridesharing

TNC

VMT
Automated mobility on demand

Automated vehicles

Automated vehicle and public transportation

San Francisco Bay Area MATSim

Bay Area Rapid Transit

Fully connected and automated vehicle

Single passenger door-to-door service

Shared door-to-door service

Greenhouse gas emissions

Metropolitan Transportation Commission

Metropolitan Transportation Commission Activity-Based Model

Shared ride with pick-up/drop-off service

Transportation network company

Vehicle miles traveled 


\section{Endnotes}

${ }^{1}$ Rodier et al., "Automated Vehicle Scenarios: Simulation of System-Level Travel Effects Using Agent-Based Demand and Supply Models in the San Francisco Bay Area," UC Davis: National Center for Sustainable Transportation (2018), retrieved from https://escholarship.org/uc/item/4dk3n531.

${ }^{2}$ National Academies of Sciences, Engineering, and Medicine, Ridesharing as a Complement to Transit, Washington, D.C.: The National Academies Press (2012).

${ }^{3}$ Simon Shepherd and Helen Muir, "Strategic Modelling Results," European Commission (2011), 42.

${ }^{4}$ Luis M. Martinez and Jose M. Viegas, "Assessing the Impacts of Deploying a Shared SelfDriving Urban Mobility System: An Agent-Based Model Applied to the City of Lisbon, Portugal," International Journal of Transportation Science and Technology 6, no. 1 (2017): 13-27.

${ }^{5}$ Stiglic et al., "Enhancing Urban Mobility: Integrating Ride-Sharing and Public Transit," Computers \& Operations Research 90 (2018): 12-21.

${ }^{6}$ Arthur Maheo, Philip Kilby, and Pascal Van Hentenryck, "Benders Decomposition for the Design of a Hub and Shuttle Public Transit System," Transportation Science 53, no. 1 (2017): $77-$ 88; Xiao Liang, Goncalo H. de A. Correia, and Bart van Arem, "Optimizing the Service Area and Trip Selection of an Electric Automated Taxi System Used for the Last Mile of Train Trips," Transportation Research Part E: Logistics and Transportation Review 93 (2016): 115-129.

${ }^{7}$ Arthur Maheo, Philip Kilby, and Pascal Van Hentenryck, "Benders Decomposition for the Design of a Hub and Shuttle Public Transit System," Transportation Science 53, no. 1 (2017): 7788.

${ }^{8}$ Xiao Liang, Goncalo H. de A. Correia, and Bart van Arem, "Optimizing the Service Area and Trip Selection of an Electric Automated Taxi System Used for the Last Mile of Train Trips," Transportation Research Part E: Logistics and Transportation Review 93 (2016): 115-129.

${ }^{9} \mathrm{Yu}$ Xin Chen, "Simulation-Based Design of Integrated Public Transit and Shared Autonomous Mobility-on-Demand Systems," Doctoral Dissertation, Massachusetts Institute of Technology, 2018.

${ }^{10}$ Basu et al., "Automated Mobility-on-Demand vs. Mass Transit: A Multi-Modal ActivityDriven Agent-Based Simulation Approach," Transportation Research Record 11 (2018); International Transport Forum, "Shared Mobility Simulations for Dublin," International Transport Forum Policy Papers 58 (2018); Yu Shen, Hongmou Zhang, and Jinhua Zhao, "Integrating Shared Autonomous Vehicle in Public Transportation System: A Supply-Side Simulation of the FirstMile Service in Singapore," Transportation Research Part A: Policy and Practice 113 (2018): 125136; Jian Wen, Yu X. Chen, Neema Nassir, and Jinhua Zhao, "Transit-Oriented Autonomous 
Vehicle Operation with Integrated Demand-Supply Interaction," Transportation Research Part C: Emerging Technologies 97 (2018): 216-234.

${ }^{11}$ Basu et al., "Automated Mobility-on-Demand vs. Mass Transit: A Multi-Modal ActivityDriven Agent-Based Simulation Approach,” Transportation Research Record 11 (2018).

${ }^{12}$ International Transport Forum, "Shared Mobility Simulations for Dublin," International Transport Forum Policy Papers 58 (2018).

${ }^{13} \mathrm{Yu}$ Shen, Hongmou Zhang, and Jinhua Zhao, "Integrating Shared Autonomous Vehicle in Public Transportation System: A Supply-Side Simulation of the First-Mile Service in Singapore," Transportation Research Part A: Policy and Practice 113 (2018): 125-136.

${ }^{14}$ Jian Wen, Yu X. Chen, Neema Nassir, and Jinhua Zhao, "Transit-Oriented Autonomous Vehicle Operation with Integrated Demand-Supply Interaction," Transportation Research Part C: Emerging Technologies 97 (2018): 216-234.

${ }^{15}$ Lawrence D. Burns, "Sustainable Mobility: A Vision of our Transport Future," Nature 497 (2013): 181.

${ }^{16}$ T. S. Stephens et al., "Estimated Bounds and Important Factors for Fuel Use and Consumer Costs of Connected and Automated Vehicles," National Renewable Energy Laboratory (2016).

${ }^{17}$ Daniel J. Fagnant and Kara Kockelman, "Preparing a Nation for Autonomous Vehicles: Opportunities, Barriers and Policy Recommendations," Transportation Research Part A: Policy and Practice 77 (2015): 167-181.

${ }^{18}$ Brian A. Johnson, “Disruptive Mobility, Research Report,” Barclays (2015).

${ }^{19}$ Patrick M. Bösch et al., "Cost-Based Analysis of Autonomous Mobility Services," Transport Policy 64 (2018): 76-91; Todd Litman, "Autonomous Vehicle Implementation Predictions," Victoria Transport Policy Institute (2017).

${ }^{20}$ Todd Litman, “Autonomous Vehicle Implementation Predictions," Victoria Transport Policy Institute (2017).

${ }^{21}$ Patrick M. Bösch et al., "Cost-Based Analysis of Autonomous Mobility Services," Transport Policy 64 (2018): 76-91.

${ }^{22}$ See Farzard Alemi and Caroline J. Rodier, "Simulation of Ridesourcing Using Agent-Based Demand and Supply Models Regional: Potential Market Demand for First Mile Transit Travel and Reduction in Vehicle Miles Traveled in the San Francisco Bay Area," 97 $7^{\text {th }}$ Annual Meeting of the Transportation Research Board (2018).

${ }^{23}$ See Farzard Alemi and Caroline J. Rodier, "Simulation of Ridesourcing Using Agent-Based Demand and Supply Models Regional: Potential Market Demand for First Mile Transit Travel 
and Reduction in Vehicle Miles Traveled in the San Francisco Bay Area," $97^{\text {th }}$ Annual Meeting of the Transportation Research Board (2018).

${ }^{24}$ See Farzard Alemi and Caroline J. Rodier, "Simulation of Ridesourcing Using Agent-Based Demand and Supply Models Regional: Potential Market Demand for First Mile Transit Travel and Reduction in Vehicle Miles Traveled in the San Francisco Bay Area," 97 $7^{\text {th }}$ Annual Meeting of the Transportation Research Board (2018).

${ }^{25}$ For a more detailed description of the algorithms, see Joschka Bischoff et al., "Competition among Automated Taxis, Transit, and Conventional Passenger Vehicles: Traffic Effects in the San Francisco Bay Area (No. 19-02178)," 98 ${ }^{\text {th }}$ Annual Meeting of the Transportation Research Board (2019). 


\section{Bibliography}

Alemi, Farzard, and Caroline J. Rodier. "Simulation of Ridesourcing Using Agent-Based Demand and Supply Models Regional: Potential Market Demand for First Mile Transit Travel and Reduction in Vehicle Miles Traveled in the San Francisco Bay Area." Presented at the $97^{\text {th }}$ Annual Meeting of the Transportation Research Board (2018).

Basu, Rounaq, Andrea Araldo, Arun P. Akkinepally, Bat H. N. Biran, Kalaki Basak, Ravi Seshadri, Neeraj Deshmukh, Nishant Kumar, Carlos L. Azevedo, and Moshe BenAkiva. "Automated Mobility-on-Demand vs. Mass Transit: A Multi-Modal ActivityDriven Agent-Based Simulation Approach.” Transportation Research Record 11 (2018).

Bischoff, Joschka, Caroline J. Rodier, Elham Pourrahmani, Miguel Jaller, Anmol Pahwa, and Michal Maciejewski. "Competition among Automated Taxis, Transit, and Conventional Passenger Vehicles: Traffic Effects in the San Francisco Bay Area (No. 19-02178)." 98 ${ }^{\text {th }}$ Annual Meeting of the Transportation Research Board (2019).

Bösch, Patrick M., Felix Becker, Henrick Becker, and Kay W. Axhausen. "Cost-Based Analysis of Autonomous Mobility Services.” Transport Policy 64 (2018): 76-91. https://doi.org/10.1016/j.tranpol.2017.09.005

Burns, Lawrence D. "Sustainable Mobility: A Vision of our Transport Future." Nature 497 (2013): 181.

Chen, Yu Xin. "Simulation-Based Design of Integrated Public Transit and Shared Autonomous Mobility-on-Demand Systems.” Doctoral Dissertation, Massachusetts Institute of Technology, 2018.

Fagnant, Daniel J., and Kara Kockelman. "Preparing a Nation for Autonomous Vehicles: Opportunities, Barriers and Policy Recommendations.” Transportation Research Part A: Policy and Practice 77 (2015): 167-181. https://doi.org/10.1016/j.tra.2015.04.003

International Transport Forum. "Shared Mobility Simulations for Dublin." International Transport Forum Policy Papers 58 (2018).

Jaller, Miguel, Elham Pourrahmani, Caroline J. Rodier, and Joschka Bischoff. "SimulationOptimization Framework to Evaluate a Sustainable First Mile Transit Access Program Using Shared Mobility.” Presented at the $98^{\text {th }}$ Annual Meeting of the Transportation Research Board (2019).

Johnson, Brian A. "Disruptive Mobility.” Research Report, Barclays (2015). 
Liang, Xiao, Goncalo H. de A. Correia, and Bart van Arem. "Optimizing the Service Area and Trip Selection of an Electric Automated Taxi System Used for the Last Mile of Train Trips." Transportation Research Part E: Logistics and Transportation Review 93 (2016): 115-129. https://doi.org/10.1016/j.tre.2016.05.006

Litman, Todd. “Autonomous Vehicle Implementation Predictions." Victoria [British Columbia, Canada] Transport Policy Institute (2017).

Maheo, Arthur, Philip Kilby, and Pascal Van Hentenryck. "Benders Decomposition for the Design of a Hub and Shuttle Public Transit System." Transportation Science 53, no. 1 (2017): 77-88. https://doi.org/10.1287/trsc.2017.0756

Martinez, Luis M., and Jose M. Viegas. "Assessing the Impacts of Deploying a Shared SelfDriving Urban Mobility System: An Agent-Based Model Applied to the City of Lisbon, Portugal." International Journal of Transportation Science and Technology 6, no. 1 (2017): 13-27. https://doi.org/10.1016/j.ijtst.2017.05.005

National Academies of Sciences, Engineering, and Medicine. Ridesharing as a Complement to Transit. Washington, D.C.: The National Academies Press (2012). https://doi.org/10.17226/14655

Rodier, Caroline J., Miguel Jaller, Elham Pourrahmani, Joschka Bischoff, Joel Freedman, and Anmol Pahwa. "Automated Vehicle Scenarios: Simulation of System-Level Travel Effects Using Agent-Based Demand and Supply Models in the San Francisco Bay Area.” UC Davis: National Center for Sustainable Transportation (2018). Retrieved from https://escholarship.org/uc/item/4dk3n531.

Shen, Yu, Hongmou Zhang, and Jinhua Zhao. "Integrating Shared Autonomous Vehicle in Public Transportation System: A Supply-Side Simulation of the First-Mile Service in Singapore." Transportation Research Part A: Policy and Practice 113 (2018): 125-136. https://doi.org/10.1016/j.tra.2018.04.004

Shepherd, Simon, and Helen Muir. "Strategic Modelling Results." European Commission (2011), 42.

Stephens, T. S., Jeff Gonder, Yuche Chen, Z. Lin, C. Liu, and D. Gohlke. "Estimated Bounds and Important Factors for Fuel Use and Consumer Costs of Connected and Automated Vehicles." National Renewable Energy Laboratory (2016). https://doi.org/10.2172/1334242

Stiglic, Mitja, Niels Agatz, Martin Savelsbergh, and Mirko Gradisar. "Enhancing Urban Mobility: Integrating Ridesharing and Public Transit." Computers \& Operations Research 90 (2018): 12-21. https://doi.org/10.1016/j.cor.2017.08.016 
Wen, Jian, Yu X. Chen, Neema Nassir, and Jinhua Zhao. "Transit-Oriented Autonomous Vehicle Operation with Integrated Demand-Supply Interaction.” Transportation Research Part C: Emerging Technologies 97 (2018): 216-234.

https://doi.org/10.1016/j.trc.2018.10.018 


\section{About the Authors}

\section{Caroline Rodier}

Dr. Caroline Rodier is a Researcher at the Institute of Transportation Studies, University of California, Davis (UC Davis). Her primary areas of research include transport, land use, and environmental policy analysis. Her current modeling research involves the travel and equity effects and financial sustainability of alternative new shared mobility systems (e.g., transit-based and regional ridehailing and ridesharing), including automated vehicles.

\section{Andrea Broaddus}

Dr. Andrea Broaddus is a transportation policy expert focused on managing the demand for travel through behavioral incentives and land use practices. She has published articles on road pricing and transit-oriented development and has served as a lecturer at UC Berkeley and San Jose State since 2010.

\section{Miguel Jaller}

Miguel Jaller is an Associate Professor in Civil and Environmental Engineering at UC Davis. Dr. Jaller's research interests are in the areas of freight transportation, sustainable transportation systems, and humanitarian logistics. He has published scientific and technical publications on these topics and has presented at different national and international venues.

\section{Jeffery Song}

Jeffery Song is a postdoctoral researcher in the 3 Revolutions Future Mobility Program at the University of California, Davis. He earned his Ph.D. at Carnegie Mellon University in Engineering and Public Policy.

\section{Joschka Bischoff}

Dr. Joschka Bischoff is currently a simulation expert at the Swiss Federal Railways as part of the business development team. He recently received his Ph.D. from the Technical University of Berlin. He is a recognized expert in the simulation of automated vehicle systems.

\section{Yunwan Zhang}

Yunwan Zhang is a research data analyst at the Institute of Transportation Studies, University of California, Davis. She earned her Masters of Science degree in Civil and Environmental Engineering at UC Davis. 


\section{Hon. Norman Y. Mineta}

\section{MTI BOARD OF TRUSTEES}

Founder, Honorable Norman

Mineta*

Secretary (ret.),

US Department of Transportation

Chair,

Abbas Mohaddes

President \& COO

Econolite Group Inc.

Vice Chair,

Will Kempton

Executive Director

Sacramento Transportation Authority

Executive Director,

Karen Philbrick, PhD*

Mineta Transportation Institute

San José State University

Winsome Bowen

Chief Regional Transportation

Strategy

Facebook

David Castagnetti

Co-Founder

Mehlman Castagnetti

Rosen \&Thomas

\section{Maria Cino}

Vice President

America \& U.S. Government

Relations Hewlett-Packard

Enterprise

\author{
Grace Crunican** \\ Owner \\ Crunican LLC
}

Donna DeMartino

Managing Director

Los Angeles-San Diego-San Luis

Obispo Rail Corridor Agency

Nuria Fernandez**

General Manager \& CEO

Santa Clara Valley Transportation

Authority (VTA)

\section{John Flaherty}

Senior Fellow

Silicon Valley American

Leadership Form

William Flynn *

President \& CEO

Amtrak

Rose Guilbault

Board Member

Peninsula Corridor

Joint Powers Board

Ian Jefferies*

President \& CEO

Association of American

Railroads
Diane Woodend Jones

Principal \& Chair of Board

Lea + Elliott, Inc.

David S. Kim*

Secretary

California State Transportation

Agency (CALSTA)

Therese McMillan

Executive Director

Metropolitan Transportation

Commission (MTC)

Bradley Mims

President \& CEO

Conference of Minority

Transportation Officials

(COMTO)

Jeff Morales

Managing Principal

InfraStrategies, LLC

Dan Moshavi, PhD*

Dean, Lucas College and Graduate

School of Business

San José State University

Toks Omishakin*

Director

California Department of

Transportation (Caltrans)
Takayoshi Oshima

Chairman \& CEO

Allied Telesis, Inc.

Paul Skoutelas*

President \& CEO

American Public Transportation

Association (APTA)

Beverley Swaim-Staley

President

Union Station Redevelopment

Corporation

Jim Tymon*

Executive Director

American Association of

State Highway and

Transportation Officials

(AASHTO)

Larry Willis*

President

Transportation Trades

Dept.,AFL-CIO

* = Ex-Officio

${ }^{* *}=$ Past Chair, Board of Trustees

\section{Directors}

Karen Philbrick, PhD

Executive Director

Hilary Nixon, PhD

Deputy Executive Director

Asha Weinstein Agrawal, PhD

Education Director

National Transportation Finance

Center Director

\section{Brian Michael Jenkins}

National Transportation Security

Center Director

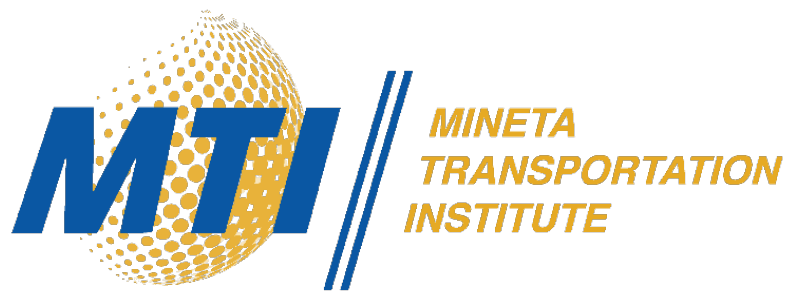

